\title{
Cortisol Inhibition of Calcium Currents in Guinea Pig Hippocampal CA1 Neurons via G-Protein-coupled Activation of Protein Kinase C
}

\author{
Jarlath M. H. ffrench-Mullen \\ Department of Pharmacology, Zeneca Pharmaceuticals Group, Zeneca Inc., Wilmington, Delaware 19897
}

The inhibition of voltage-activated $\mathrm{Ca}^{2+}$ channel currents by cortisol (hydrocortisone), the principal glucocorticoid in man and guinea pig, was examined in freshly dissociated pyramidal neurons from the adult guinea pig hippocampal CA1 region using whole-cell voltage-clamp recordings. Steadystate inhibition by cortisol of the peak $\mathrm{Ca}^{2+}$ channel current evoked by depolarization from -80 to $-10 \mathrm{mV}$ increased in a concentration-dependent fashion, with a maximal inhibition of $63 \pm 4 \%$ of the total current at $100 \mu \mathrm{m}$. Cortisone had a maximal $17 \pm 2 \%$ inhibition at $10 \mu \mathrm{M}$. Corticosterone and the metabolite allotetrahydrodeoxycorticosterone exhibited a plateau of inhibition of around $15 \%$ and $25 \%$, respectively, between $10 \mathrm{pm}$ and $100 \mathrm{~nm}$; both compounds continued to inhibit at concentrations $>10^{-7} \mathrm{M}$. Analysis of tail currents at $-80 \mathrm{mV}$ showed that cortisol and corticosterone had no effect on the voltage-dependent activation or deactivation of the $\mathrm{Ca}^{2+}$ channel current. However, cortisol slowed the activation of the current. Cortisol inhibited both the $\mathrm{N}$-type or $\omega$-conotoxin (CgTX)-sensitive, and the L-type or nifedipine (NIF)-sensitive $\mathrm{Ca}^{2+}$ channel current but had no effect on the $\mathrm{CgTX} / \mathrm{NIF}$-insensitive $\mathrm{Ca}^{2+}$ channel current.

In neurons isolated from pertussis toxin (PTX)-treated animals, the cortisol inhibition was significantly diminished. Intracellular dialysis with GDP- $\beta$-S $(500 \mu \mathrm{M})$ or with the specific inhibitors of protein kinase $C$ (PKC), the pseudosubstrate PKC inhibitor (PKCI 19-31) (2 $\mu \mathrm{M})$ and bisindolylmaleimide (BIS) (1 $\mu \mathrm{M})$ significantly diminished the cortisol inhibition of the $\mathrm{Ca}^{2+}$ channel current. The specific inhibitor of CAMP-dependent protein kinase (PKA) inhibitor, Rp-cAMPS $(100 \mu \mathrm{M})$ had no effect. These results demonstrate that cortisol is a potent modulator of both the CgTX- and NIF-sensitive $\mathrm{Ca}^{2+}$ channel current but not the $\mathrm{CgTX} / \mathrm{NIF}$-insensitive current. This Inhibition is via a PTX-sensitive G-protein-coupled mechanism associated with the activation of PKC.

[Key words: cortisol, corticosterone, glucocorticoid, calcium channel, w-conotoxin, nifedipine, G-protein, PKCl

The hippocampus has a high density of adrenal corticosteroid receptors, and is a principal target for the glucocorticoids (Reul and de Kloet, 1985). Corticosterone (CORT) binding studies in rodent CNS have identified two receptor types: the mineralo-

\footnotetext{
Received June 6, 1994; revised July 15, 1994; accepted July 19, 1994.

I thank K. Spence and P. Danks for technical assistance, and Dr. C. R. PlataSalamán for his assistance with the pertussis toxin experiments.

Correspondence should be addressed to J. M. H. ffrench-Mullen, Ph.D., at the above address.

Copyright (c) 1995 Society for Neuroscience $0270-6474 / 95 / 150903-09 \$ 05.00 / 0$
}

corticoid receptor (MR), which binds CORT with a high affinity and is primarily in the septohippocampal system, and the glucocorticoid reccptor (GR), which has an approximate 10 -fold lower affinity for CORT and has quite a ubiquitous distribution (Reul and de Kloet, 1985; de Kloet, 1991). Low plasma concentrations of CORT predominantly occupy MRs, while increasing CORT levels, such as at the peak circadian cycle and following stress, will additionally activate GRs in addition to MRs (Reul and de Kloet, 1985). Cortisol and cortisone bind to the GRs while CORT binds to GRs and MRs; hippocampal pyramidal CAl neurons contain both MRs and GRs (for review, see de Kloet, 1991).

The endogenous corticosteroids (cortisol, cortisone, and CORT) are known to stimulate a number of biochemical and genomic processes in hippocampal neurons (de Kloet, 1991; McEwen, 1991). Earlier extracellular recordings revealed a disparity of cortisol and CORT effects, which included excitation, inhibition, or no change in neuronal firing (for review, see Joëls and de Kloet, 1992). The effects of the glucocorticoids on CNS excitability are dependent on their concentration in the external milieu, as recent electrophysiological findings with CORT in the rat have demonstrated that these biphasic effects are due to the status of receptor occupancy, such as MR, or GR, or both (Joëls and de Kloet, 1993). Studies have shown that MR activation decreases, whereas GR activation increases with a considerable time lag, the accommodation and the $\mathrm{Ca}^{2+}$-dependent, $\mathrm{K}$ ' -mediated afterhyperpolarization (AHP) following brief depolarizing pulses (Kerr et al., 1989; Joëls and de Kloet, 1990), and that protein synthesis is required (Karst and Joëls, 1991). In hippocampal neurons from adrenalectomized animals, $\mathrm{Ca}^{2+}$ action potentials are reduced (Kerr et al., 1989); however, under singleelectrode voltage clamp, the voltage-activated $\mathrm{Ca}^{2+}$ currents were increased following a prolonged $(2 \mathrm{hr})$ exposure to a high concentration $(7 \mu \mathrm{M})$ of the specific GR agonist RU 28362, an effect that was blocked by a protein synthesis inhibitor (Kerr et al., 1992).

Synaptic transmission at the rat Schaeffer collateral-CA1 synapses in the hippocampus is enhanced by low levels of CORT while higher CORT concentrations decrease synaptic transmission (Rey et al., 1987). It was recently concluded that while steroid receptor occupation, particularly MR occupancy, is necessary for maintenance of synaptic transmission during repeated stimulation, higher (30 nM) CORT levels, hence MR and GR occupancy, rapidly depressed synaptic transmission, reducing both the EPSP and slow IPSP with no change in membrane properties (Joëls and de Kloet, 1993). However, $>1 \mu \mathrm{M}$ CORT depressed the fast IPSP in rat hippocampal CAl and neocortical 
neurons with no change in membrane properties (Zeise et al., 1992).

Long-term potentiation (LTP), the enhancement of synaptic transmission following a tetanic priming, has been suggested to underlie some types of memory and learning functions in the CNS (Bliss and Lynch, 1988; Lynch and Staubli, 1991). Experimental (behavioral) and clinical studies have shown that glucocorticoids have an important role in learning and memory processes (McEwen, 1987; Wolkowitz et al., 1990). Acute stress impairs LTP, and acute and chronic glucocorticoid administrafion reduces LTP in both the hippocampal CAl and dentate fields (Dubrovsky et al., 1993; Pavlides et al., 1993). Prolonged (lasting for months) elevations of glucocorticoids induced by either chronic CORT administration or stress are toxic to hippocampal pyramidal neurons, particularly in the CA fields. Increased CORT levels have been implicated in the changes seen in CA fields during aging (Sapolsky et al., 1985; Landfield, 1987). The hippocampus's role in human memory and learning is well established, as is that the hippocampus is essential for the consolidation of short-term memory, declarative or explicit memory, and spatial memory (for review, see Squire, 1992). Blood cortisol levels are increased in depressed patients, particularly aged patients (see von Bardeleben and Holsboer, 1991). Aged patients showing increased cortisol levels also show impaired cognitive performance (Lupien et al., 1994).

Corticosteroids have a broad spectrum of action and exert their main actions through specific receptors. Cortisol has a direct and inhibitory action on the nicotinic cholinergic receptor (Bouzat and Barrantes, 1992), and some neurosteroids directly and rapidly depress voltage-gated $\mathrm{Ca}^{2+}$ channel currents in CA1 neurons (ffrench-Mullen et al., 1994). Cortisol, the prototypic and principal glucocorticoid in human, is also in the principal glucocorticoid in guinea pig (Depaolo and Masoro, 1989). This is in contrast to rat and mouse, which produce predominantly corticosterone. In this study, cortisol is shown to inhibit rapidly a fraction of the voltage-gated $\mathrm{Ca}^{2+}$ channel currents, specifically, the $\mathrm{N}$ - and L-type $\mathrm{Ca}^{2+}$ currents. This inhibition is modulated via PTX-sensitive G-protein(s) and the activation of PKC.

\section{Materials and Methods}

Implantation of brain cannulas and osmotic minipumps. Brain cannulas and osmotic minipumps were implanted as previously described in detail (ffrench-Mullen et al., 1994). Guinea pigs were allowed to recover for 7-10 d after surgery before osmotic minipump implantation. Alzet osmotic minipumps (Alza Corporation, CA) were used to accomplish the continuous intracerebroventricular microinfusion of pertussis toxin $(1000 \mathrm{ng} / 24 \mathrm{hr}$ for $48 \mathrm{hr}$ ). The nominal pumping rate of the osmotic minipumps is $1 \mu \mathrm{l} / \mathrm{hr} / 7 \mathrm{~d}$ (model 2001). For minipump implantation, the guinea pigs were anesthetized with sodium pentobarbital. The filled minipump was connected, by a short polyethylene tube (1.1 $\mathrm{mm}$ i.d.), to an insert cannula of 29 gauge stainless steel tubing, L-shaped so that when inserted into the guide cannula its terminal end just reached the tip of the guide cannula. The minipump was inserted into the subcutaneous interscapular space, and the L-shaped steel tubing was cemented in place with dental acrylic.

Cell preparation and whole-cell patch-clamp recording. Pyramidal neurons were acutely isolated from the CAl region of the mature guinea pig hippocampus as previously described (ffrench-Mullen et al., 1994) and immediately used in electrophysiological experiments. Macroscopic whole-cell $\mathrm{Ca}^{2+}$ channel currents were recorded at room temperature $\left(22-25^{\circ} \mathrm{C}\right)$ using $3 \mathrm{~mm} \mathrm{Ba}^{2+}$ as the external charge-carrying divalent cation, and with the $\mathrm{Ca}^{2+}$ chelator $\mathrm{Cs}_{4}-\mathrm{BAPTA}$ (Molecular Probes, Eugene, OR) in the intracellular solution to reduce $\mathrm{Ca}^{2+}$-promoted $\mathrm{Ca}^{2+}$ channel inactivation (Eckart and Chad, 1984). The bath solution contained (in $\mathrm{mM}$ ) $\mathrm{BaCl}_{2}, 3$; tetraethylammonium chloride (TEA-Cl), 140; $\mathrm{MgCl}_{2}, 1$; HEPES, 10; and glucose, 6 . Tetrodotoxin $(2 \mu \mathrm{M})$ was added to the bath solution to block voltage-dependent $\mathrm{Na}^{+}$channels, and the solution was adjusted to $\mathrm{pH} 7.4$ with fresh $\mathrm{CsOH}$ solution and to an osmolality of $320 \mathrm{mOsm} / \mathrm{kg} \mathrm{H} \mathrm{H}_{2} \mathrm{O}$. The pipette solution contained (in $\mathrm{mM}$ ) $\mathrm{N}$ - methyl-D-glucamine chloride, 120; $\mathrm{Cs}_{4}$-BAPTA, 5; and $\mathrm{Mg}$ ATP, 5. The ATP regeneration system Tris-phosphocreatinine ( $20 \mathrm{mM})$ and creatine kinase $(20 \mathrm{U} / \mathrm{ml})$ was added to the internal solution to minimize rundown of the $\mathrm{Ca}^{2+}$ currents (ffrench-Mullen et al., 1994). The internal solution was adjusted to $\mathrm{pH} 7.2$ with fresh $\mathrm{CsOH}$ and to an osmolality of $315 \mathrm{mOsm} / \mathrm{kg} \mathrm{H}_{2} \mathrm{O}$. The rate of rundown under these conditions was $<5 \%$ over a $30 \mathrm{~min}$ period.

Recordings were carried out using the whole-cell patch-clamp technique as previously described (ffrench-Mullen et al., 1994). Evoked currents were filtered at $10 \mathrm{kHz}(-3 \mathrm{~dB}, 8$-pole low-pass Bessel filter; Frequency Devices, Haverhill, MA), digitally sampled at $500 \mu \mathrm{sec}$ per point ( $50 \mu \mathrm{sec}$ per point for tail current measurements), and stored on magnetic media in digital form for later analysis. Capacitative and leakage currents were digitally subtracted from all records, which was carried out on line by using pCLAMP 5.51 (Axon Instruments). Capacitative transients decayed with a time constant of $100 \mu \mathrm{sec}$. A rapid superfusion system consisting of a side-by-side array of six $200 \mu \mathrm{m}$ i.d. capillary tubes was positioned approximately within $500 \mu \mathrm{m}$ of the cell under study. Drug solutions were applied by gravity feed and flow was computer controlled via solenoid valves (BME Systems, Baltimore, MD). Solution changes were accomplished within $300-500 \mathrm{msec}$. $\mathrm{Ca}^{2+}$ currents were typically evoked by $200 \mathrm{msec}$ voltage steps to $-10 \mathrm{mV}$ from a holding potential of $-80 \mathrm{mV}$ at $30 \mathrm{sec}$ intervals to examine the inhibition of cortisol on peak current, and the respective types of $\mathrm{Ca}^{2+}$ currents. The $10 \mathrm{msec}$ voltage steps (evoked at $15 \mathrm{sec}$ intervals) were generated to examine the tail currents.

Data analysis. For the quantitation of inhibition, peak current values were used. Percentage inhibition was determined according to the formula $100 \times\left(1-I_{\text {drug }} / I_{\text {control }}\right)$, where $I_{\text {control }}$ is the leak-subtracted peak current amplitude prior to the drug application and $I_{\text {drus }}$ is the peak current amplitude in the presence of the test drug. During the drug applications, the $\mathrm{Ca}^{2+}$ current was examined with the $200 \mathrm{msec}$ duration depolarizing step protocols. Steady-state inhibition was typically achieved within 30-240 sec after the onset of the drug superfusion. The $I_{\text {drus }}$ value used in the calculation of percentage block was obtained after being at a steady-state value for $1 \mathrm{~min}$. Concentration-effect data were fitted with a nonlinear least squares program (NFIT, Island Products, Galveston, TX) according to the logistical equation $B=100 /\left\{1+\left(\mathrm{IC}_{50} /\right.\right.$ [DRUG] $\left.{ }^{n H}\right\}$, where [DRUG] is the drug concentration, $\mathrm{IC}_{50}$ is the concentration resulting in $50 \%$ block, and $n H$ is an empirical parameter that describes the steepness of the curve and has the same meaning as the Hill coefficient. Tail current amplitudes were estimated by fitting the falling phasc of the current to a single exponential and extrapolating the curve to zero time. Activation curves were determined by plotting tail current amplitudes at $-80 \mathrm{mV}$ following activation of current by test pulses to different voltages, and were fitted by the Boltzmann equation $\left\{1+\exp \left[\left(V_{1 / 2}-V\right) / K\right]\right\}^{-1}$, where $V_{1 / 2}$ is the voltage for halfmaximal activation and $K$ is the slope factor. Fitting was done by NFIT and/or TABLECURve (Jandel Scientific, Corte Madera, CA). All traces are the average of three steps and are leak subtracted except where noted; current-voltage $(I-V)$ data points at each potential are connected by a cubic spline in SIGMAPLOT. Final plotting was performed with sIGMAPLOT. All quantitative data are expressed as mean $\pm \mathrm{SEM} ; n$ indicates the number of cells examined. Statistical analysis was performed using the paired or unpaired Student's $t$ test; results were considered significant only for $P<0.05$.

Chemicals. All reagents used in this study, exccpt where noted, were obtained from Sigma (St. Louis, MO) and included the following: cortisol (hydrocortisone), cortisone, corticosterone, $3 \alpha, 5 \alpha$-pregnane-3 $\alpha, 21$ diol-20-one (allotetrahydrodeoxycorticosterone, THDOC), nifedipine, pertussis toxin (PTX), guanosine 5 '- $O$-(2-thiodiphosphate) (GDP- $\beta$-S); $\omega$ - conotoxin GVIA (CgTX; Peninsula Laboratories, Belmont, CA); $R p$ cyclic adenosine $3^{\prime}, 5^{\prime}$-monophosphothioate (Rp-cAMPS), $S p$-cyclic adenosine 3',5'-monophosphothioate (Sp-cAMPS), 3-[1-(3-dimethylaminopropyl)-indol-3-yll-3-(indol-3-yl)-maleimide or bisindolylmaleimide (BIS) (Calbiochem, San Diego, CA); and PKCI 19-31 pseudosubstrate inhibitor (Bachem Bioscience, Inc., Philadelphia, PA). Stock solutions $(10 \mathrm{~mm})$ of the steroids in ethanol were prepared daily; with steroid concentrations of $100 \mu \mathrm{M}$, final ethanol volume never exceeded $0.1 \%$ and the latter had no effect on the $\mathrm{Ca}^{2+}$ current. Stock solutions (10 mM) of nifedipine and $\omega$-conotoxin were prepared weckly in ethanol and $\mathrm{H}_{2} \mathrm{O}$, respectively. 


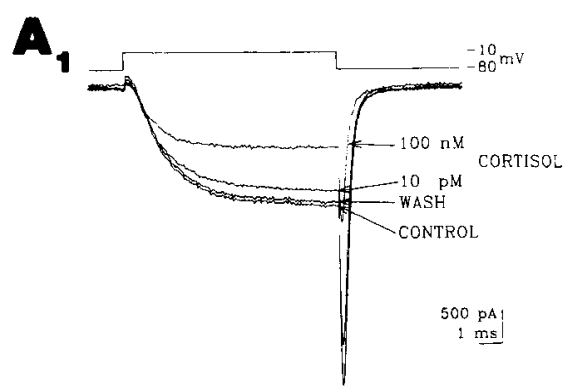

2

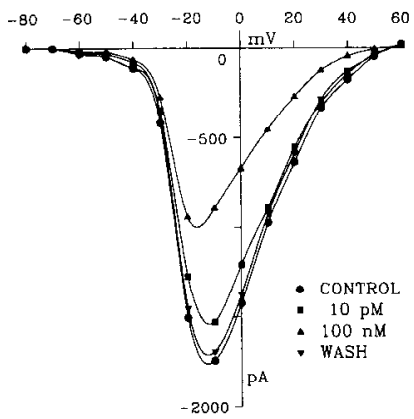

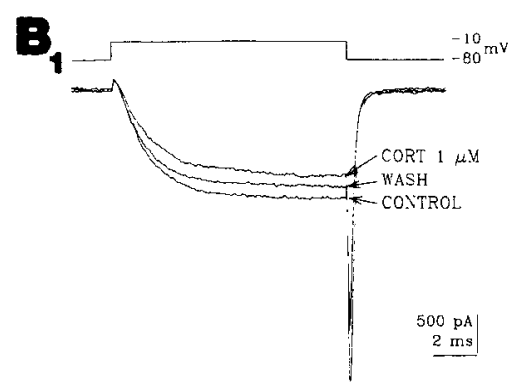

2

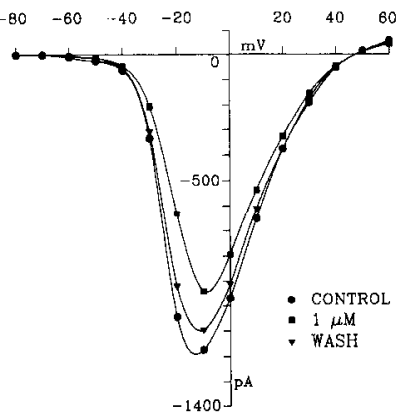

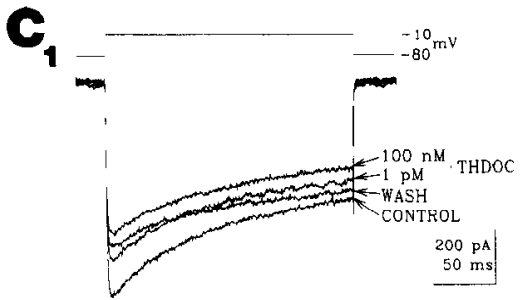

2

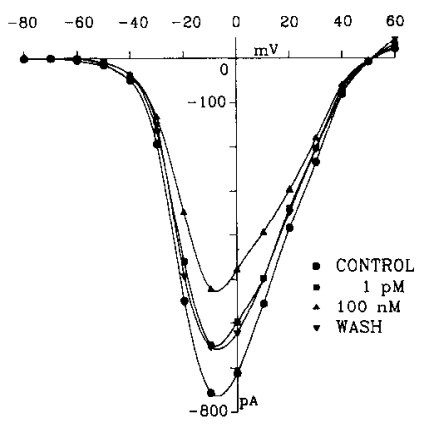

Figure 1. Corticosteroid inhibition of whole-cell $\mathrm{Ca}^{2+}$ channel currents in guinea pig hippocampal CA1 neurons. Ca ${ }^{2+}$ channel currents were elicited by either $10 \mathrm{msec}(A$ and $B)$ or $200 \mathrm{msec}(C)$ depolarizing voltage steps over the range of -80 to $+60 \mathrm{mV}$ from a holding potential of -80 $\mathrm{mV}$ in three different neurons using $3 \mathrm{mM} \mathrm{Ba}^{2+}$ as the charge carrier. The individual (leak-subtracted) step currents recorded at -10 mV are illustrated. $A_{l}$, Reversible, concentration-dependent inhibition of pcak and tail currents by cortisol. $A_{2}$, Peak $\mathrm{Ca}^{2+}$ channel current (mcasurcd 0.5 msec prior to the end of the step) plotted as a function of membrane potential (current-voltage, $I-V)$ in the absence $(0)$, presence of 10 pM $(\square)$ and $100 \mathrm{nM}(\Lambda)$ cortisol, and wash ( $\boldsymbol{\nabla})$. In $A$ and $B, I-V$ values were obtained at steady-state values acquired with $200 \mathrm{msec}$ voltage steps. $B_{l}$, Corticosterone

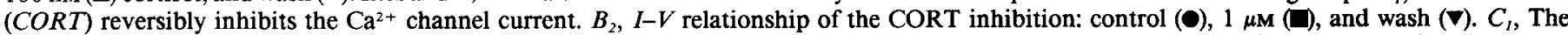
corticosterone metabolite allotetrahydrodeoxycorticosterone (THDOC) reversibly inhibits the $\mathrm{Ca}^{2+}$ channel current in a concentration-dependent manner. $C_{2}, I-V$ relationship of the concentration-dependent inhibition by THDOC: control $(\bullet), 1$ pM $(\mathbb{D}), 100 \mathrm{nM}(\boldsymbol{\Delta})$, and wash $(\nabla)$.

\section{Results}

The data presented in this report represent the results of wholecell recordings of $\mathrm{Ca}^{2+}$ channel current from more than 120 neurons acutely dissociated from adult guinea pig hippocampal CA1 neurons. Macroscopic voltage-gated $\mathrm{Ca}^{2+}$ channel currents were recorded using $3 \mathrm{~mm} \mathrm{Ba}^{2+}$ as the external charge-carrying cation.

\section{Inhibition of the $\mathrm{Ca}^{2+}$ current}

Depolarizing voltage steps from $-80 \mathrm{mV}$ to various potentials positive to $-60 \mathrm{mV}$ elicited a high-threshold inward current (HVA) that peaked rapidly, and decayed gradually with maintained depolarizations (Fig. 1C). Superfusion with $50 \mu \mathrm{M} \mathrm{Cd}^{2+}$ virtually eliminated the inward current $(97 \pm 3 \%$ block, $n=5$; not shown), demonstrating that it is carried by $\mathrm{Ca}^{2+}$ channels. Peak $\mathrm{Ca}^{2+}$ channel current was reduced in a concentration-dependent fashion by cortisol, corticosterone (CORT), and allotetrahydrodeoxycorticosterone (THDOC), acquiring steady-state values over the concentration range examined at 30-240 sec, with the fastest time to inhibition occurring for the highest concentrations (1-100 $\mu \mathrm{M})$. The concentration-dependent inhibition by cortisol, CORT, and THDOC is illustrated in Figure 1.

Brief $(10 \mathrm{msec})$ depolarizing voltage steps were acquired over the range of -80 to $+60 \mathrm{mV}$ in $10 \mathrm{mV}$ increments to examine the effect of cortisol and CORT on the current-voltage $(I-V)$ relationship of the peak and tail currents, respectively. Between generation of the $I-V$ traces, $200 \mathrm{msec}$ depolarizing steps from

80 to $10 \mathrm{mV}$ wcre acquired to assess control and steadystate drug values; thus, $I-V$ traces were generated at steady-state values. Figure $1 A_{I}$ illustrates the $\mathrm{Ca}^{2+}$ channel current in the absence and presence of cortisol at $-10 \mathrm{mV}$. In this neuron, the peak current (measured $0.5 \mathrm{msec}$ prior to the end of the step) was reversibly inhibited by 10 pm and $100 \mathrm{~nm}$ cortisol. The $I-V$ relationship in the presence of cortisol showed a greater inhibition of peak current between -30 and $0 \mathrm{mV}$ at $10 \mathrm{pm}$; at $100 \mathrm{nM}$, cortisol had a greater inhibitory effect between -20 and $+50 \mathrm{mV}$ (Fig. $1 A_{2}$ ). Tail current amplitude measured at $-80 \mathrm{mV}$ following the step to $-10 \mathrm{mV}$ was also reversibly depressed by cortisol. CORT also depressed the $\mathrm{Ca}^{2+}$ channel current, as illustrated in Figure $1 B_{l}$. In this cell, peak $\mathrm{Ca}^{2+}$ current was reversibly depressed $21 \%$ by $1 \mu \mathrm{M}$ CORT. For comparison, we also examined the potent $\mathrm{GABA}_{\mathrm{A}}$ potentiator THDOC, an endogenous corticosterone metabolite (Fig. 1C). Here, $200 \mathrm{msec}$ depolarizing voltage steps were acquired over the range of -80 to $+60 \mathrm{mV}$. As shown in Figure $1 C_{l}$, THDOC reversibly depressed the inward $\mathrm{Ca}^{2+}$ current: $24 \%$ and $31 \%$ peak current depression for 1 pm and $100 \mathrm{~nm}$, respectively, with a wash to $83 \%$ of control.

The concentration-effect relationships for the steady-state inhibition of the peak $\mathrm{Ca}^{2+}$ channel current by these compounds were examined with $200 \mathrm{msec}$ depolarizing voltage steps to - 10 $\mathrm{mV}$ from a holding potential of $-80 \mathrm{mV}$. All three compounds qualitatively exhibited similar biphasic dose-effect curves (Fig. 2). At low concentrations, all of these steroids reversibly inhibit the $\mathrm{Ca}^{2+}$ channel current in a concentration-dependent manner (Fig. 2). As the concentrations of all the steroids are increased, there appears to be a plateau effect of their inhibition of the current, which is quite pronounced for CORT and THDOC between $10 \mathrm{pm}$ and $100 \mathrm{~nm}$ (Fig. 2). The plateau effect of cortisol 
Figure 2. Concentration-effect curves for the cortisol-, corticosterone-, and allotetrahydrodeoxycorticosterone (THDOC)-induced inhibition of the peak $\mathrm{Ca}^{2+}$ channel current evoked by $200 \mathrm{msec}$ voltage steps from a holding potential of $-80 \mathrm{mV}$ to a test potential of $-10 \mathrm{mV}$. Each point represents the mean \pm SEM of 5-11, 5-7, and 9-20 neurons for cortisol, THDOC, and corticosterone, respectively.

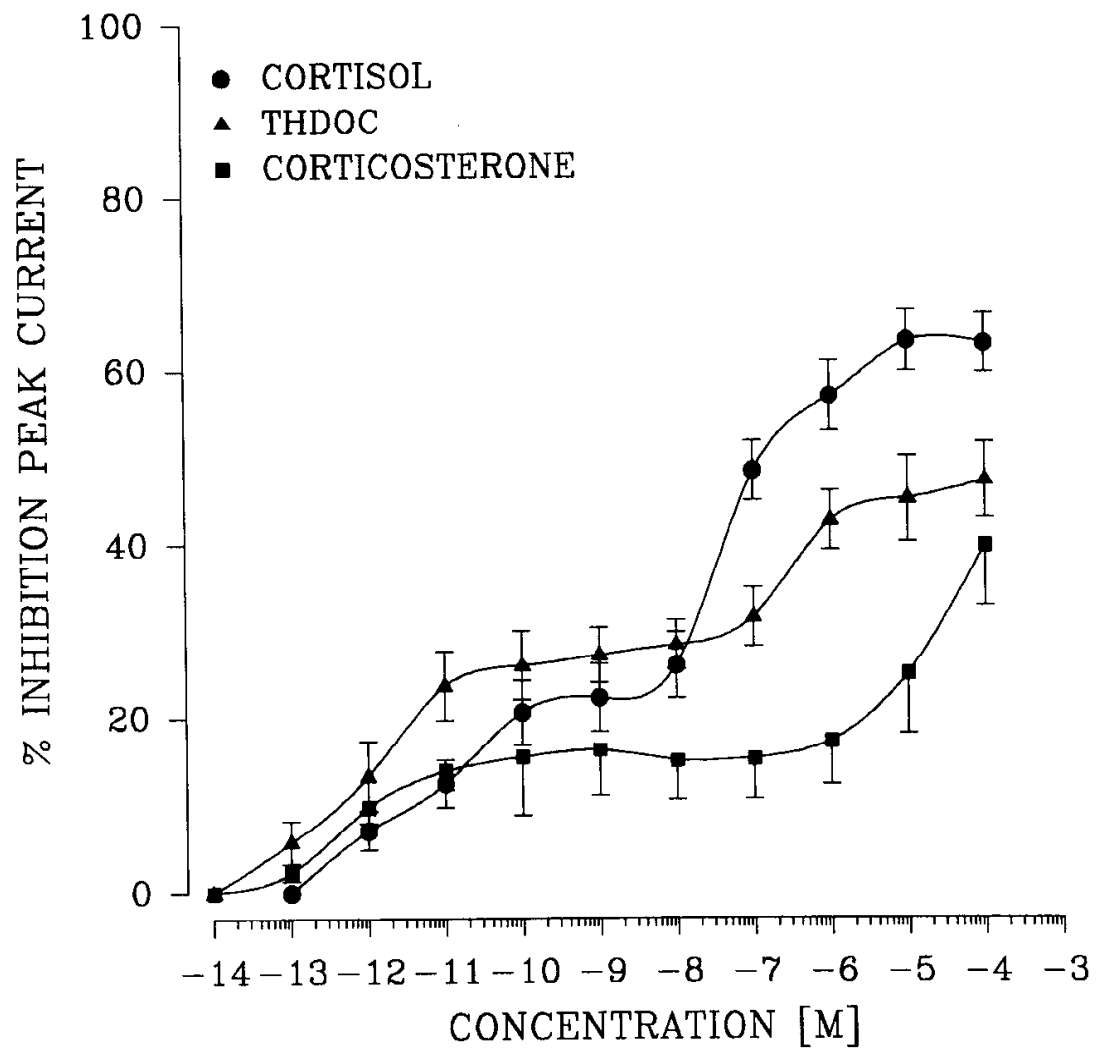

is, however, much less pronounced and over a smaller range of $100 \mathrm{pm}$ to $100 \mathrm{~nm}$. Cortisol gave a maximum inhibition at saturating concentrations that inhibited a fraction $(63 \pm 4 \%)$ of the total $\mathrm{Ca}^{2+}$ channel current at 10 and $100 \mu \mathrm{M}$. An apparent sigmoidal fit (not shown; $R=0.9987$ ) to the data gave an approximate $\mathrm{IC}_{50}$ of $5 \mathrm{nM}$ and an $n H$ of 0.5 , suggesting multiple binding sites. In addition, at the maximal concentration (100 $\mu \mathrm{M})$ there was minimal reversibility ( $79 \pm 5 \%, n=9)$ of control in wash with control solution. However, $>1 \mu \mathrm{M}$ CORT continued to inhibit the $\mathrm{Ca}^{2+}$ channel current, suggesting a nonselective mode of action, while THDOC appeared to exhibit another plateau phase (Fig. 2). Cortisone exhibited a small reversible inhibition of the peak $\mathrm{Ca}^{2+}$ current: $2 \pm 0.8 \%, 5 \pm 2 \%, 13 \pm$ $1 \%, 14 \pm 2 \%, 16 \pm 2 \%$, and $17 \pm 2 \%$ inhibition for $10 \mathrm{pm}$, $100 \mathrm{pm}, 1 \mathrm{nM}, 10 \mathrm{nM}, 1 \mu \mathrm{M}$, and $10 \mu \mathrm{M}$ cortisone, respectively ( $n=5$; not shown). Following the $10 \mu \mathrm{M}$ concentration, the cortisone inhibition reversed to $95 \pm 4 \%$ of control with wash $(n=5)$. There was minimal or no reversibility of the CORT and THDOC inhibition seen at concentrations $>10 \mu \mathrm{M}$.

\section{Activation and deactivation kinetics}

The effect of cortisol on the voltage dependence of activation of the $\mathrm{Ca}^{2+}$ channel conductance was examined. Smooth curves to the peak tail currents (measured at $-80 \mathrm{mV}$ following a depolarizing voltagc stcp to various potentials) were fit according to a Boltzmann distribution (not shown). For the cell in Figure $1 A$, there was a minimal shift to the right by cortisol, where the voltage at which half the channels are open $\left(V_{1 / 2}\right)$ was $-18.2,-16.2$, and $-16.3 \mathrm{mV}$, and slope amplitude $(k)$ was 6 , 6.1 , and $6.3 \mathrm{mV}$ for control, $10 \mathrm{pm}$, and $100 \mathrm{~nm}$ cortisol, respectively. For all cells examined with cortisol, there was no change: $V_{1 / 2},-17.9 \pm 0.25,-17 \pm 0.46$, and $-17 \pm 0.67 \mathrm{mV}$, and $k, 6.2 \pm 0.2,6.3 \pm 0.22$, and $6.3 \pm 0.15 \mathrm{mV}$ for control,
10 pM and 100 nM cortisol, respectively $(n=3)$. A lack of effect was also observed with CORT for the cell in Figure $1 \mathrm{~B}$, where the $V_{1 / 2}$ was -17 and $-16.4 \mathrm{mV}$, and $k$ was 8 and $7.5 \mathrm{mV}$ (Fig. $1 B)$. The $V_{1 / 2}$ and $k$ for all cells were not changed with CORT: $V_{1 / 2},-17.8 \pm 0.2$ and $-17.5 \pm 0.3 \mathrm{mV}$, and $k, 6.8 \pm 0.3$ and $6.5 \pm 0.3 \mathrm{mV}$ for control and $1 \mu \mathrm{M}$ CORT, respectively $(n=$ 3).

To determine whether cortisol had an effect on the time course of deactivation of the $\mathrm{Ca}^{2+}$ channel current, we examined the tail currents generated at $-80 \mathrm{mV}$ following a depolarization to $-10 \mathrm{mV}$. In control conditions, the tail currents in these neurons are well fitted by a single exponential function to give a single time constant (ffrench-Mullen et al., 1994). For the neuron in Figure $1 A_{l}$, cortisol essentially had no effect on the deactivation of the tail current, where the time constant $(\tau)$ was $240,230,240$, and $240 \mu \mathrm{sec}$ for control, $10 \mathrm{pm}$ and $100 \mathrm{~nm}$ cortisol, and wash, respectively. On a total of three cells examined, cortisol had no significant effect $(P>0.2)$ on the deactivation of the tail current: $\tau$ was $237 \pm 8,228 \pm 5,225 \pm$ $7,227 \pm 6$, and $230 \pm 5 \mu \mathrm{sec}$ for control, $1 \mathrm{pM}, 10 \mathrm{pM}, 100$ $\mathrm{nM}$, and $1 \mu \mathrm{M}$ cortisol, respectively. For the neuron in Figure $1 B_{l}$, CORT also had no effect on the deactivation of the tail current, where $\tau$ was 220,219 , and $219 \mu \mathrm{sec}$ for control, $1 \mu \mathrm{M}$ CORT, and wash, respectively (Fig. $1 B_{1}$ ). On the three cells examined, CORT had no effect on the tail current deactivation; $\tau=230 \pm 0.02,225 \pm 0.02$, and $225 \pm 0.02 \mu \mathrm{sec}$ for control, $1 \mathrm{nM}$ and $1 \mu \mathrm{M}$ CORT, respectively.

In the presence of cortisol, qualitative observations of the currents showed an apparent slowing of the rising phase or time to peak of the inward $\mathrm{Ca}^{2+}$ channel current generated by 200 msec depolarizing steps in these CAl neurons. To examine this, the activation or time to peak was fittcd to a single exponential function, and was well described by a single $\tau$ (not shown). 
Cortisol significantly $(P<0.02)$ slowed the time to peak of the $\mathrm{Ca}^{2+}$ channel current at concentrations greater than $100 \mathrm{pM}$, where $\tau$ was $0.99 \pm 0.09,1.12 \pm 0.11,1.18 \pm 0.03$, and 1.27 $\pm 0.08 \mathrm{msec}$ for control, $1 \mathrm{nM}, 100 \mathrm{nM}$, and $1 \mu \mathrm{M}$ cortisol, respectively $(n=9)$. CORT also significantly $(P<0.003)$ slowed the time to peak of the $\mathrm{Ca}^{2+}$ channel current, where $\tau$ was 0.84 $\pm 0.08,0.88 \pm 0.06,0.96 \pm 0.04,1.2 \pm 0.04$, and $1.27 \pm 0.04$ msec for control, $10 \mathrm{pM}, 1 \mathrm{nM}, 100 \mathrm{nM}$, and $1 \mu \mathrm{M}$ CORT, respectively $(n=9)$.

\section{Cortisol and $\mathrm{Ca}^{2+}$ channel subtypes}

In hippocampal neurons, multiple types of $\mathrm{HVA} \mathrm{Ca}^{2+}$ channels exist that, at the whole-cell level, have been pharmacologically classified into various subtypes, including the $\mathrm{N}$-, L-, and P-currents (Mogul and Fox, 1991; O'Dell and Alger, 1991; Regan et al., 1991; Mintz et al., 1992). The low-threshold or T-type current is not present in the adult guinea pig CA1 cells (Doerner and Alger, 1988; Thompson and Wong, 1991). Similar to guinea pig CA3 (Mogul and Fox, 1991) and rat hippocampal CA1 (Regan et al., 1991; Mintz et al., 1992) neurons, the HVA current in guinea pig CAl neurons consists of an N-type or CgTXsensitive current (see Fig. $4 A$, hatched bars) and an L-type or NIF-sensitive current (see Fig. $4 B$, hatched bars), which together inhibit approximately $40 \%$ of the total $\mathrm{HVA} \mathrm{Ca}^{2+}$ current, as well as a fraction that is $\mathrm{CgTX} / \mathrm{NIF}$ insensitive (see Fig. $4 C$ ). It was previously reported that the dihydropyridine agonist \pm Bay $\mathrm{K} 8644(0.1-1 \mu \mathrm{M})$ increased the peak inward $\mathrm{Ca}^{2+}$ current at test potentials of -50 to $+10 \mathrm{mV}$ and shifted the $I-V$ relationship in the hyperpolarizing direction, which was blocked by 10 $\mu \mathrm{M}$ NIF, while $10 \mu \mathrm{M} \mathrm{CgTX}$ produced no shift in the $I-V$ relationship (ffrench-Mullen et al., 1994). For this study, the resistant $\mathrm{Ca}^{2+}$ current reflects that current insensitive to both $\mathrm{CgTX}$ and NIF.

The fraction(s) of the $\mathrm{Ca}^{2+}$ channel current modulated by cortisol was first examined by application of cortisol in the presence of $10 \mu \mathrm{M} \mathrm{NIF}$. As illustrated in Figure $3 \mathrm{~A}$, following the inhibition of the L-type current, concomitant increasing concentrations of cortisol continucd to inhibit a fraction of the $\mathrm{Ca}^{2+}$ channel current. The results of the cortisol inhibition in the presence of $\mathrm{CgTX}$ and NIF are summarized in Figure 4. In the presence of $10 \mu \mathrm{M} \mathrm{CgTX,} \mathrm{there} \mathrm{was} \mathrm{a} 2 \pm 1 \%, 6 \pm 2 \%, 9$ $\pm 4 \%$, and $16 \pm 5 \%$ inhibition of the $\mathrm{Ca}^{2+}$ channel current for $1 \mathrm{pM}, 100 \mathrm{pM}, 10 \mathrm{nM}$, and $10 \mu \mathrm{M}$ cortisol, respectively (Fig. $4 A$ ). In the presence of $10 \mu \mathrm{M}$ NIF, there was a $3 \pm 1 \%, 7 \pm 3 \%, 10$ $\pm 3 \%$, and $12 \pm 3 \%$ inhibition for $1 \mathrm{pm}, 100 \mathrm{pm}, 10 \mathrm{~nm}$, and $10 \mu \mathrm{M}$ cortisol, respectively (Fig. $4 B$ ). However, cortisol had no effect on the CgTX/NIF-insensitive or resistant current: $0.5 \pm$ $1 \%, 0.8 \pm 1 \%, 1 \pm 3 \%$, and $1 \pm 3 \%$ inhibition for 1 pM, 100 pM, $10 \mathrm{~nm}$, and $10 \mu \mathrm{M}$ cortisol, respectively (Fig. 4C). These results suggested that while cortisol had no effect on the $\mathrm{CgTX} /$ NIF-insensitive current, it inhibited both the $\mathrm{N}$ - and L-type $\mathrm{Ca}^{2+}$ channel currents. The amount of cortisol inhibition in the presence of either CgTX or NIF was substantially reduced when compared with control values (see Fig. 2), which demonstrated that CgTX and NIF dramatically occluded the inhibitory effect of cortisol.

\section{$G$-protein mediation of the cortisol inhibition}

The possible involvement of G-proteins in the cortisol inhibition of the $\mathrm{Ca}^{2+}$ channel current was tested by examining neurons treated with pertussis toxin (PTX). Of the G-proteins expressed in neurons, some are sensitive to PTX (such as $\mathrm{G} \alpha_{\mathrm{i}}$ and
$\mathrm{G} \alpha_{\mathrm{n}}$ ), which prevents their interaction by catalyzing their ADP ribosylation (Gilman, 1987). Animals were pretreated for $48 \mathrm{hr}$ with PTX at $1000 \mathrm{ng} / 24 \mathrm{hr}$; following this, neurons were then acutely isolated from the CAl region. The characteristics of neurons (such as peak current amplitude) isolated from PTXtreated animals were the same as normal or nontreated animals (ffrench-Mullen et al., 1994). In addition, PTX had no effect on the NIF inhibition (a channel blocker) of the $\mathrm{Ca}^{2+}$ channel current $(n=3)$, as previously reported (ffrench-Mullen et al., 1994).

An example of the effect of PTX on the cortisol inhibition of the $\mathrm{Ca}^{2+}$ channel current is illustrated in Figure $3 B$, where peak current inhibition at $10 \mu \mathrm{M}$ was $15 \%$, compared to $63 \%$ in control (see Fig. 2). PTX significantly diminished the cortisol inhibition at all concentrations examined except 1 pM $(P<0.005$; maximum $18 \pm 3 \%$ inhibition at $10 \mu \mathrm{M}$ ) (Fig. $5 \mathrm{~A}$ ).

Further verification of the possible involvement of G-protein(s) was obtained with neurons dialyzed with the nonhydolyzable GTP analog GDP- $\beta-S(500 \mu \mathrm{M})$, which inhibits the activation of G-proteins (Eckstein et al., 1979). GDP- $\beta$-S alone has no effect on the $\mathrm{Ca}^{2+}$ channel current (ffrench-Mullen et al., 1994). However, GDP- $\beta$-S significantly diminished the cortisol inhibition at all concentrations cxamincd except 1 pM $(P<$ 0.005 ; maximum $22 \pm 5 \%$ inhibition at $10 \mu \mathrm{M}$ ) (Fig. $5 A$ ).

\section{Involvement of $P K C$ with the cortisol inhibition}

It was concluded from these experiments that the cortisol inhibition of the $\mathrm{Ca}^{2+}$ channel current(s) was mediated via a G-protein-coupled mechanism. The modulation of $\mathrm{Ca}^{21}$ channels by $\mathrm{G}$-protein-coupled receptors involves a variety of mechanisms. This is either by direct action of the activated $\alpha$-subunit or via intracellular mediators (for review, see Hille, 1992). To determine whether cortisol activation of a G-protein(s) and coupling to $\mathrm{Ca}^{2+}$ channels involved intracellular mediators such as PKC and the cAMP-dependent protein kinase (PKA), we examined the effects of specific inhibitors of PKC and PKA. A specific inhibitor of PKC, the synthetic pseudosubstrate inhibitor PKCI 19-31 (House and Kemp, 1987), is believed to be effective against all forms of PKC (Bell and Burns, 1991; Orr et al., 1992). Bisindolylmaleimide (BIS), a compound related to staurosporine (a relatively nonspecific $\mathrm{PKC}$ inhibitor; Ruëg and Burgess, 1989), is a potent and highly selective inhibitor of PKC (Toullec et al., 1991). The characteristics of neurons internally dialyzed with BIS and PKCI 19-31 were the same as those not dialyzed with these compounds. Following the normal runup of the $\mathrm{Ca}^{2+}$ channel current, PKCI 19-31 and BIS had no effect on the amplitude and the time to peak of the $\mathrm{Ca}^{2+}$ channel current (not shown; $n=3$, respectively). The effect of internal dialysis of PKCI 19-31 $(2 \mu \mathrm{M})$ is shown in Figure $3 C$. The cortisol inhibition of the peak $\mathrm{Ca}^{2+}$ channel current was $9 \%$ and $14 \%$ at $10 \mathrm{nM}$ and $10 \mu \mathrm{M}$, respectively, compared with control (see Fig. 2). Figure $5 B$ summarizes the results of internal dialysis of both PKCI 19-31 (2 $\mu \mathrm{M})$ and BIS $(1 \mu \mathrm{M})$; there was a significant diminution $(P<0.006$, respectively) of the cortisol inhibition of the $\mathrm{Ca}^{2+}$ channel current at all concentrations except 1 pM. The maximal cortisol inhibition at $10 \mu \mathrm{M}$ was $13 \pm 4 \%$ and 14 $\pm 2 \%$ for PKCI 19-31 and BIS, respectively.

The specific membrane-permeable and competitive inhibitor of PKA, Rp-cAMPS, which competes with cAMP for the binding site on the regulatory subunit of PKA, and Sp-cAMPS were also examined (Dostmann et al., 1990; Frey et al., 1993). Bath application of Rp-cAMPS $(100 \mu \mathrm{M}, \mathrm{n}=4)$ and Sp-cAMPS (100 
A

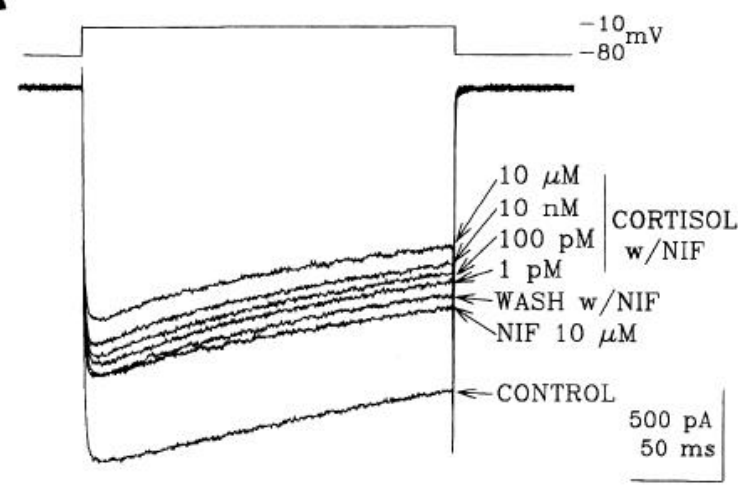

B

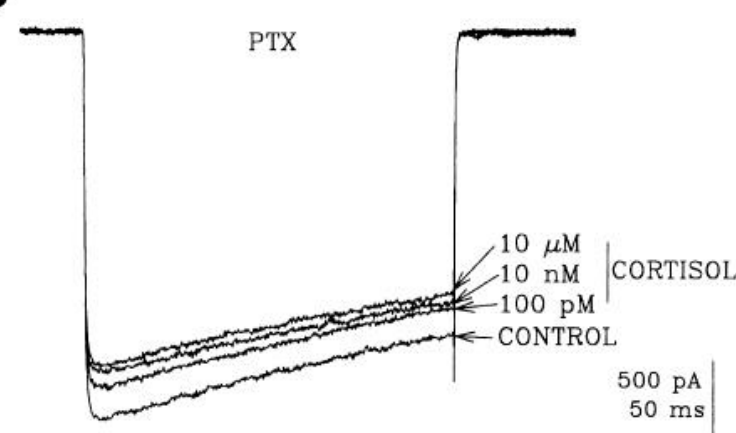

C

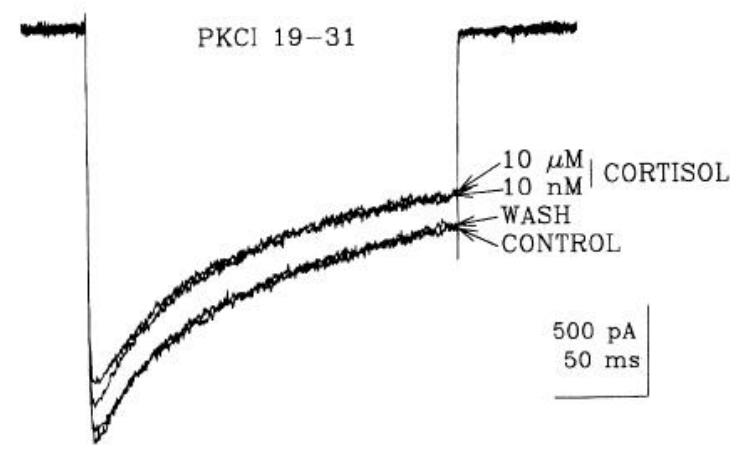

Figure 3. Diminution of the cortisol $\mathrm{Ca}^{2+}$ channel current inhibition by modulators of the L-type $\mathrm{Ca}^{2+}$ current, G-proteins, and protein kinase $\mathrm{C}$ (PKC). $A$, cortisol inhibits the $\mathrm{Ca}^{2+}$ channel current in the presence of nifedipine $(N I F)$. Following the perfusion of NIF, concomitant perfusion of increasing concentrations of cortisol inhibited the current; this inhibition was reversible with an NIF wash. $B$, Pertussis toxin $(P T X)$ greatly diminished the cortisol inhibition of the $\mathrm{Ca}^{2+}$ channel current. Neurons were acutely isolated from PTX-treated animals; see Materials and Methods for details. $C$, Internal dialysis of the specific pseudosubstrate PKC inhibitor PKCI 19-31 (2 $\mu \mathrm{M})$ also greatly reduced the amount of inhibition by cortisol.

$\mu \mathrm{M}, \mathrm{n}=3$ ) had no effect on the $1 \mu \mathrm{M}$ cortisol inhibition of the $\mathrm{Ca}^{2+}$ channel current: $58 \pm 3 \%$ and $57 \pm 4 \%$ inhibition for $\mathrm{Rp}$ cAMPS and Sp-cAMPS, respectively, compared with $57 \pm 4 \%$ inhibition for $1 \mu \mathrm{M}$ cortisol. This suggested a lack of involvement of PKA in the cortisol inhibition.

\section{Discussion}

In guinea pig and human, cortisol is the principal glucocorticoid produced, in contrast to the rat and mouse, which predomi-

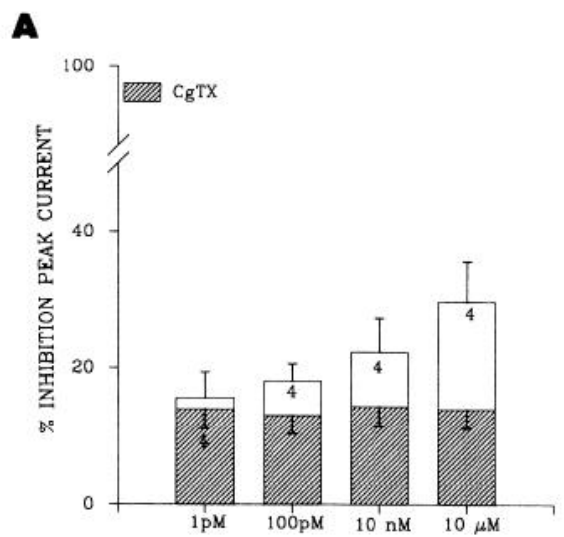

B

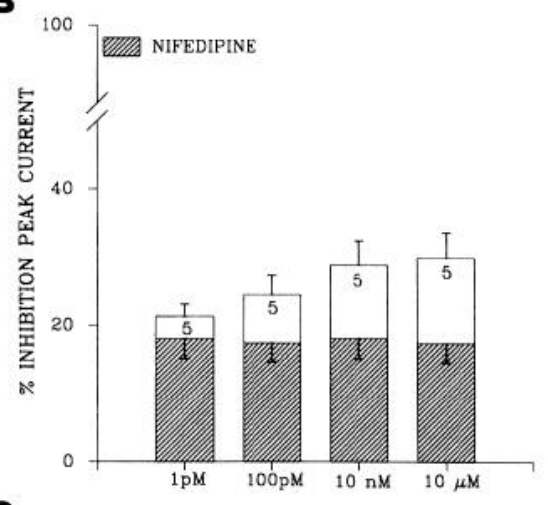

C.

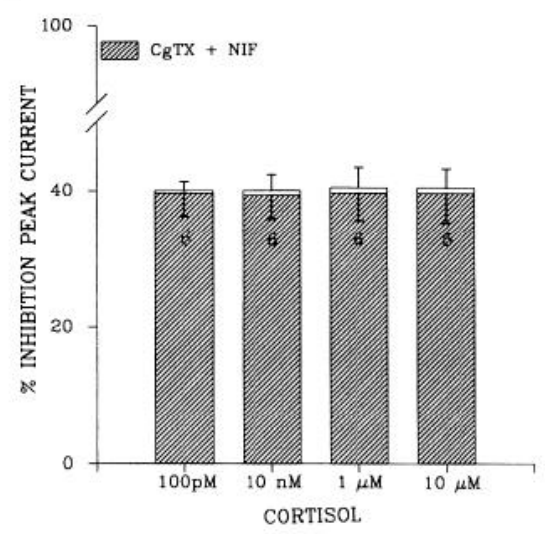

Figure 4. Cortisol inhibits both the $\omega$-conotoxin-GVIA $(\mathrm{CgTX})$ - and nifedipine $(N I F)$-sensitive but not the $\mathrm{CgTX} / \mathrm{NIF}$-insensitive $\mathrm{Ca}^{2+}$ channel currents. Data were taken from the peak current evoked by 200 msec voltage steps from a holding potential of $-80 \mathrm{mV}$ to a test potential of $-10 \mathrm{mV}$. $A$, In the presence of $10 \mu \mathrm{M} \mathrm{CgTX}$ (inhibition of the N-type $\mathrm{Ca}^{2+}$ channel current; hatched bars), cortisol inhibits an additional fraction but not all the remaining current (open bars). $B$, In the presence of $10 \mu \mathrm{M}$ NIF (inhibition of the L-type $\mathrm{Ca}^{2+}$ channel current; hatched bars), cortisol continues to inhibit some, but not all, of the remaining current. Both CgTX and NIF dramatically occlude the inhibitory effect of cortisol. $C$, In the presence of both CgTX and NIF (inhibition of $\mathrm{N}$-/and L-type $\mathrm{Ca}^{2+}$ channel current; hatched bars), cortisol essentially had no effect (open bars). Data are expressed as mean \pm SEM; number of neurons examined is given in each column.

nantly produce CORT (Depaolo and Masoro, 1989). All of the glucocorticoids in this study rapidly depressed the $\mathrm{HVA} \mathrm{Ca}{ }^{2+}$ channel current in the picomolar range with similar profiles. Cortisol potently and reversibly inhibited the $\mathrm{Ca}^{2+}$ channel current, with a maximal inhibition of $63 \%$ and an approximate 
A

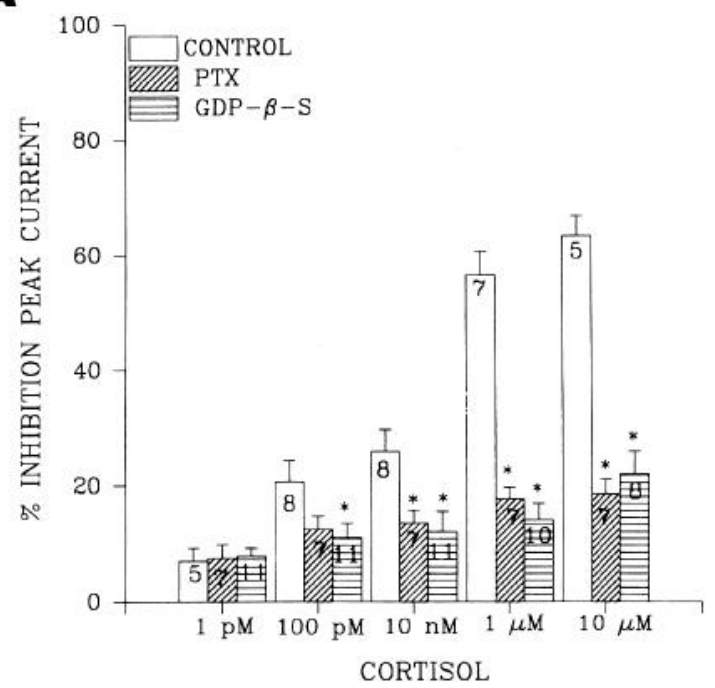

$\mathbf{B}$

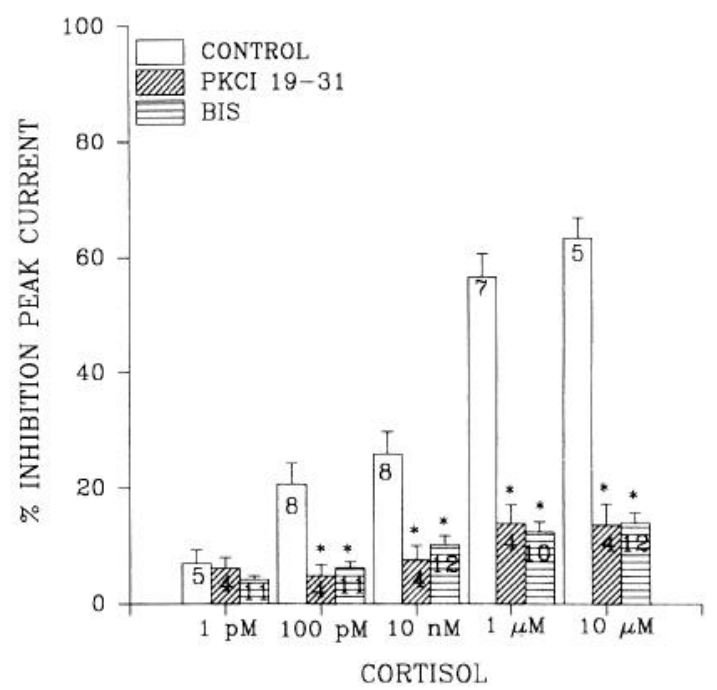

Figure 5. A G-protein mechanism coupled to activation of protein kinase $\mathrm{C}$ modulates the cortisol $\mathrm{Ca}^{2+}$ channel current inhibition. All control data were taken from Figure 2. $A$, Pertussis toxin $(P T X)$-sensitive G-protein involvement. Neurons were isolated from PTX-treated animals (1000 $\mathrm{ng} / 24 \mathrm{hr}$ for $48 \mathrm{hr}$; see Materials and Methods for details); GDP- $\beta-\mathrm{S}(500 \mu \mathrm{M})$ was internally dialyzed through the patch pipette. Both PTX and GDP- $\beta$-S significantly $\left(^{*}, P<0.005\right)$ reduced the cortisol Ca ${ }^{2+}$ channel current inhibition over the range of 100 pM to $10 \mu \mathrm{M}$. $B$, Cortisol inhibition of the $\mathrm{Ca}^{2+}$ channel current involves activation of PKC. The specific pseudosubstrate PKC inhibitor PKCI 19-31 (2 $\left.\mu \mathrm{M}\right)$ and the specific PKC inhibitor bisindolylmaleimide $(B I S ; 1 \mu \mathrm{M})$ were internally dialyzed through the patch pipette. Both PKCI $19-31$ and BIS significantly $(*, P<0.006)$ reduced the cortisol inhibition of the $\mathrm{Ca}^{2+}$ channel current. Data are expressed as mean $\pm \mathrm{SEM}$; number of neurons examined is given in each column.

$\mathrm{IC}_{50}$ value of $5 \mathrm{~nm}$. Due to the differential affinity, low corticosteroid concentrations (pM) predominantly occupy MRs, while higher concentrations ( $>10 \mathrm{~nm}$ ) will also activate GRs in rat (Reul and de Kloet, 1985). This might explain the biphasic doseeffect curves observed with these compounds. In rat, cortisol binds to the GRs while CORT binds to both MRs and GRs (see de Kloet, 1991). This would suggest that the cortisol inhibition of the $\mathrm{Ca}^{2+}$ channel current in guinea pig might be mediated via the GRs; however, this does not exclude the possibility of MR occupancy in guinea pig, which could also explain the biphasic dose-effect curve for cortisol. At concentrations that occupy both MRs and GRs ( $30 \mathrm{nM})$, CORT reduced the amplitude of both the EPSP and slow IPSP, and reduced the firing probability of synaptically driven action potentials at the Schaeffer collateral-CA1 synapse (Joëls and de Kloet, 1993). This reduction could be due to inhibition of voltage-gated $\mathrm{Ca}^{2+}$ current(s) by CORT, presumably at the postsynaptic and/or a presynaptic site. Furthermore, the CORT $(1 \mu \mathrm{M})$ reduction in synaptic inhibition in slices (Zeise et al., 1992) could also be due to $\mathrm{Ca}^{2+}$ channel inhibition.

Modulation of $\mathrm{Ca}^{2+}$ channel currents in numerous cell types is known to change both the time course and voltage dependence of $\mathrm{Ca}^{2+}$ currents (Carbonne and Swandulla, 1989). Cortisol and CORT slowed the activation or time to peak but did not alter the voltage dependence of activation or deactivation of the $\mathrm{Ca}^{2+}$ channel current. In contrast, while they had no effect on the voltage dependence of activation, the neurosteroids slowed both the activation and the deactivation of the $\mathrm{Ca}^{2+}$ current (ffrenchMullen et al., 1994). However, slowing of activation or time to peak of the $\mathrm{Ca}^{2+}$ channel current suggested the possible involvement of a G-protein(s) and/or intracellular mediators.

Guinea pig CA1 neurons have a whole-cell $\mathrm{Ca}^{2+}$ channel current consisting of three pharmacologically distinguished components, a CgTX-sensitive (N-type) current, an NIF-sensitive
(L-type) current, and a fraction resistant to both inhibitors, the CgTX/NIF-insensitive current. Cortisol inhibited only a fraction of the total whole-cell $\mathrm{Ca}^{2+}$ channel current, and while cortisol had no effect on the CgTX/NIF-insensitive current, it was nonselective in that it inhibited both the CgTX-and NIFsensitive currents. However, both $\mathrm{CgTX}$ and NIF dramatically occluded the inhibitory effect of cortisol, as the amount of cortisol inhibition in the presence of either CgTX or NIF was substantially reduced. In adrenalectomized rat brain slice CA1 neurons, prolonged exposure ( $>2 \mathrm{hr}$ ) to high concentrations ( 7 $\mu \mathrm{M})$ of the GR agonist RU 28362 increased the amplitude of the $\mathrm{N}$ - and $\mathrm{L}$-like $\mathrm{Ca}^{2+}$ currents via protein synthesis without affecting the voltage dependence (Kerr et al., 1992). In contrast, the present results show a rapid inhibitory effect by cortisol and CORT. A major consideration is species difference as well as the use of nonadenalectomized animals, as the present results were obtained from intact guinea pigs and opposite results were obtained from studies employing adrenalectomized rats (Kerr et al., 1992).

L-type $\mathrm{Ca}^{2+}$ channels in hippocampus appear to be predominantly localized in cell bodies and the proximal portion of the dendrites on neurons (Westenbroek et al., 1990). The distribution of the $\mathrm{N}$-type $\mathrm{Ca}^{2+}$ channels along the CA1-CA3 pyramidal neurons is dense in the dendrites relative to the cell bodies (Westenbroek et al., 1992), and synaptic activation involves the activation of $\mathrm{CgTX}$-sensitive or $\mathrm{N}$-type $\mathrm{Ca}^{2+}$ channels (Kamiya et al., 1988). Cortisol could have a regulatory effect on synaptic transmission, as N-type channels are probably important contributors to the generation of dendritic action potentials. However, in addition to affecting synaptic transmission, cortisol would also have a regulatory effect on L-type channels, thus mediating $\mathrm{Ca}^{2+}$ influx into cell bodies. The effects of cortisol on synaptic transmission in guinea pig (and human) remain to be explored.

The actions of cortisol on the CgTX- and NIF-sensitive $\mathrm{Ca}^{2+}$ 
currents appear to be mediated through a PTX-sensitive G-protein(s) since this inhibitory action was drastically reduced by intracellular dialysis of GDP- $\beta$-S and by pretreatment with PTX. Because PTX blocks the actions of both $\mathrm{G} \alpha_{\mathrm{i}}$ and $\mathrm{G} \alpha_{\mathrm{o}}$ subclasses, the identity of the specific G-protein(s) cannot be determined from these data. In rat cortex, it has been demonstrated that under physiological conditions, $\mathrm{G} \alpha_{\mathrm{s}}$ and $\mathrm{G} \alpha_{\mathrm{i}}$, but not $\mathrm{G} \alpha_{\mathrm{o}}$, are regulated by CORT (Saito et al., 1989). The present results further confirm that specific G-protein subunits are under the coordinated control of glucocorticoids in brain.

The modulation of $\mathrm{Ca}^{2+}$ channels by G-proteins may involve a variety of mechanisms, including a direct action or intracellular mediators, and more than one G-protein may be involved (Hille, 1992). There are many reports describing the actions of PKC and PKA inhibitors on $\mathrm{Ca}^{2+}$ channel currents, and the involvement of PKC in transmitter modulation of neuronal $\mathrm{Ca}^{2+}$ channels has recently been reported for some systems (see Diversé-Pierlussi and Dunlap, 1993). The G-protein-dependent cortisol inhibition of the $\mathrm{Ca}^{2+}$ channels appears to be coupled to the intracellular kinase mediator PKC. The specific inhibitors of PKC, namely, BIS and PKCI 19-31, significantly diminished the inhibitory effect of cortisol. Rp-cAMPS, a specific competitive inhibitor of PKA, had no effect on the cortisol inhibition of the $\mathrm{Ca}^{2+}$ currents, even at a concentration $(100 \mu \mathrm{M})$ known to inhibit late long-term potentiation in hippocampal slices (Frey et al., 1993). Application of Sp-CAMPS to activate PKA had no effect on the cortisol inhibition of the $\mathrm{Ca}^{2+}$ channel current. Similar results were obtained with certain neurosteroids: inhibition of the $\mathrm{Ca}^{2+}$ channel current via a PTX-sensitive G-protein and activation of PKC (ffrench-Mullen et al., 1994). Overall, the data suggest that there may be a common mechanism of action of the steroids on neuronal voltage-gated $\mathrm{Ca}^{2+}$ channel currents.

The experiments in this report were conducted on nonadrenalectomized guinea pigs. In other in vitro reports in rat, adrenalectomy was performed to avoid activation of the corticosteroid receptors and binding sites (see Kerr et al., 1989, 1992; Joëls and de Kloet, 1992, 1993). The glucocorticoid depression of the voltage-gated $\mathrm{Ca}^{2+}$ channel current in guinea pig occurs rapidly, and by physiological levels of the steroids. Cortisol levels (such as in stress or depression) could indeed have effects on neuronal firing (this and other reports; see introductory remarks) and consequently LTP and/or cellular dysfunction such as in aging. Glucocorticoids are released in response to stress and cortisol levels are elevated in depressed patients (von Bardeleben and Holsboer, 1991). Cortisol levels significantly increase in aged patients, who were impaired on tasks measuring explicit memory and selective attention, hence cognitive performance (Lupien et al., 1994). While the glucocorticoids can affect memory processes and other cognitive functions (McEwen et al., 1986; McEwen, 1987; Wolkowitz et al., 1990), they also impair LTP in both adrenalectomized (Dubrovsky et al., 1993) and nonadrenalectomized animals (Pavlides et al., 1993), and prolonged glucocorticoid elevations are toxic to hippocampal pyramidal neurons (Sapolsky et al., 1985; Landfield, 1987). Inhibition of $\mathrm{Ca}^{2+}$ entry to neurons by cortisol would inhibit LTP, and presumably memory processes overall, as $\mathrm{Ca}^{2+}$ entry is a requirement for the establishment of LTP (Bliss and Lynch, 1988). An additional implication of prolonged glucocorticoid exposure is an alteration in levels or a downregulation of the G-protein(s) modulating the $\mathrm{Ca}^{2+}$ channel current inhibition, which could in turn affect cellular function. Alterations in
G-proteins may represent a general mechanism by which neurons adapt to chronic drug treatments and other chronic perturbations in vivo.

Glucocorticoids have been shown to influence hippocampal physiology acutely, and considerable evidence exists demonstrating that selective steroids synthesized in brain and adrenal cortex have rapid membrane-mediated effects on the CNS (for a review, see Majewska, 1992). In addition, membrane receptors have been demonstrated (Orchnik et al., 1991). The present results demonstrate that physiological levels of the glucocorticoid cortisol in nonadrenalectomized animals reversibly inhibit the neuronal somatic voltage-gated $\mathrm{N}$ - and $\mathrm{L}$-type $\mathrm{Ca}^{2+}$ currents. This modulation is via a PTX-sensitive G-protein associated with the activation of PKC. This inhibition could result in a reduction of neuronal excitability, which could have profound effects on cognitive performance, particularly in scenarios known to raise cortisol levels, such as stress, depression, and aging. These effects could be further compounded by the additional genomic modulation with prolonged exposure to high glucocorticoid levels.

\section{References}

Bell R, Burns D (1991) Lipid activation of protein kinase C. J Biochem 266:4661-4664.

Bliss TVP, Lynch A (1988) Long-term potentiation of synaptic transmission in the hippocampus: properties and mechanisms. In: Neurology and neurobiology, Vol 35, Long-term potentiation: from Biophysics to behaviour (Landfield PW, Deadwyler SA, eds), pp 3-78. New York: Liss.

Bouzat C, Barrantes FJ (1992) Hydrocortisone and 11-desoxycortisone modify acetylcholine receptor channel gating. Neuroreport 4:143146.

Carbonne E, Swandulla D (1989) Neuronal calcium currents: kinetics, blockade and modulation. Prog Biophys Mol Biol 54:31-58.

de Kloet ER (1991) Brain corticosteroid receptor balance and homeostatic control. Front Endocrinol 12:95-164.

Depaolo LV, Masoro EJ (1989) Endocrine hormones in laboratory animals. In: The clinical chemistry of laboratory animals (Loeb WF, Quimby FW, eds), pp 279-308. New York: Pergamon.

Diversé-Pierlussi M, Dunlap K (1993) Distinct, convergent second messenger pathways modulate neuronal calcium currents. Neuron 10: 753-760.

Doerner D, Alger BE (1988) Cyclic GMP depresses hippocampal $\mathrm{Ca}^{2+}$ current through a mechanism independent of cGMP-dependent protein kinase. Neuron 1:693-699.

Dostmann WRG, Taylor SS, Genieser H-H, Jasteroff B, Doskeland SO, Ogried D (1990) Probing the nucleotide binding sites of cAMPdependent protein kinases I and II with analogs of adenosine $3^{\prime}, 5^{\prime}$ cyclic phosphothioates. J Biol Chem 265:10484-10491.

Dubrovsky G, Gijsbers K, Fillipini D, Birmingham MK (1993) Effects of adrenocortical steroids on long-term potentiation in the limbic system: basic mechanisms and behavioural consequences. Cell Mol Neurobiol 13:399-414.

Eckart R, Chad JE (1984) Inactivation of Ca channels. Prog Biophys Mol Biol 44:215-267.

Eckstein F, Cassel D, Levkovitz H, Lowe M, Selinger Z (1979) Guanosine $5^{\prime}-O$-(2-thiodiphosphate). An inhibitor of adenylate cyclase stimulation by guanine nucleotides and fluoride ions. J Biol Chem 254:9829-9834.

ffrench-Mullen JMH, Danks P, Spence KT (1994) Neurosteroids modulate calcium currents in hippocampal CAl neurons via a pertussis toxin-sensitive G-protein-coupled mechanism. J Neurosci 14:19631977.

Frey U, Huang Y-Y, Kandel ER (1993) Effects of cAMP stimulate a late stage of LTP in hippocampal neurons. Science 260:1661-1664.

Gilman AG (1987) G-proteins: transducers of receptor generated signals. Annu Rev Biochem 56:615-649.

Hille B (1992) G-protein coupling mechanisms and nervous system signalling. Neuron 9:187-195. 
House C, Kemp BE (1987) Protein kinase C contains a pseudosubstrate prototype in its regulatory domain. Science 238:1726-1728.

Joëls M, de Kloet ER (1990) Mineralocorticoid receptor-mediated changes in membrane properties of rat CAl pyramidal neurons in vitro. Proc Natl Acad Sci USA 87:4495-4498.

Joëls M, de Kloet ER (1992) Control of neuronal excitability by corticosteroid hormones. Trends Pharmacol Sci 15:25-30.

Joëls M, de Kloet ER (1993) Corticosteroid actions on amino acidmediated transmission in rat CA1 hippocampal cells. J Neurosci 13: 4082-4090.

Kamiya H, Sawada S, Yamamoto C (1988) Synthetic omega-conotoxin blocks synaptic transmission in the hippocampus in vitro. Neurosci Lett 91:84-88.

Karst H, Joëls M (1991) The induction of corticosteroid actions on membrane properties of hippocampal $\mathrm{CAl}$ neurons requires protein synthesis. Neurosci Lett 130:27-31.

Karst H, Wadman WJ, Joëls M (1993) Long-term control by corticosteroids of the inward rectifier in rat CA1 pyramidal neurons, in vitro. Brain Res 612:172-179.

Kerr DS, Campbell LW, Hao SY, Landfield PW (1989) Corticosterone modulation of hippocampal potentials: increased effect with aging. Science 245:1505-1509.

Kerr DS, Campbell LW, Thibault O, Landfield PW (1992) Hippocampal glucocorticoid receptor activation enhances voltage-dependent $\mathrm{Ca}^{2+}$ conductances: relevance to brain aging. Proc Natl Acad Sci USA 89:8527-8531.

Landfield PW (1987) Modulation of brain aging correlates by longterm alterations of adrenal steroids and neurally-active peptides. Prog Brain Res 72:279-300.

Lupien S, Lecours AR, Lussier I, Schwartz G, Nair NPV, Meany MJ (1994) Basal cortisol levels and cognitive deficits in human aging. J Neurosci 14:2893-2903.

Lynch G, Staubli V (1991) Possible contributions of long-term potentiation to the encoding and organization of memory. Brain Res Rev 16:204-206.

Majewska MD (1992) Neurosteroids: endogenous bimodal modulators of the $\mathrm{GABA}_{\mathrm{A}}$ receptor. Mechanism of action and physiological significance. Prog Neurobiol 38:379-395.

McEwen BS (1987) Glucocorticoid biogenic amine interactions in relation to mood and behaviour. Biochem Pharmacol 36:1755-1763.

McEwen BS (1991) Non-genomic and genomic effects of steroids on neural activity. Trends Pharmacol Sci 12:141-147.

McEwen BS, de Kloet ER, Rostene W (1986) Adrenal steroid receptors and actions in the nervous system. Physiol Rev 66:1121-1188.

Mintz IA, Adams ME, Bean BP (1992) P type calcium channels in rat central and peripheral neurons. Neuron 9:85-95.

Mogul DJ, Fox AP (1991) Evidence for multiple types of $\mathrm{Ca}^{2+}$ channels in acutely isolated hippocampal CA3 neurons. J Physiol (Lond) 433: 259-281.

O'Dell TJ, Alger BE (1991) Single calcium channels in rat and guineapig hippocampal neurons. J Physiol (Lond) 436:739-767.
Orchnik M, Murray TF, Moore FL (1991) A corticosteroid receptor in neuronal membranes. Science 252:1848-1851.

Orr J, Keranien L, Newton A (1992) Reversible exposure of the pseudosubstrate domain of protein kinase $C$ by phosphatidylserine and diacylglycerol. J Biol Chem 267:15263-15266.

Pavlides C, Watanabe Y, McEwen BS (1993) Effects of glucocorticoids on hippocampal long-term potentiation. Hippocampus 3:183-192.

Regan LJ, Sah DWY, Bean BP (1991) $\mathrm{Ca}^{2+}$ channels in rat central and peripheral neurons: high-threshold current resistant to dihydropyridine blockers and $\omega$-conotoxin. Neuron 6:269-280.

Reul JMHN, de Kloet ER (1985) Two receptor systems for corticosterone in rat brain: micro distribution and differential occupation. Endocrinology 117:2505-2512.

Rey M, Carlier E, Soumireu-Mourat B (1987) Effects of corticosterone on hippocampal slice electrophysiology in normal and adrenalectomized BALB/c mice. Neuroendocrinology 46:424-429.

Ruëg UT, Burgess GM (1989) Staurosporine, K-252 and UCN-01: potent but non-selective inhibitors of protein kinases. Trends Pharmacol Sci 10:218-220.

Saito N, Guitart X, Hayward M, Tallman JF, Duman RS, Nestler EJ (1989) Corticosterone differentially regulates the expression of $G_{w}$ and $G_{i \alpha}$ messcnger RNA and protcin in rat ccrcbral cortcx. Proc Natl Acad Sci USA 86:3906-3910.

Sapolsky RM, Krey LC, McEwen BS (1985) Prolonged glucocorticoid exposure reduces hippocampal neuron numbers: implications for aging. J Neurosci 5:1222-1227.

Squire LR (1992) Memory and the hippocampus: a synthesis from findings with rats, monkeys and humans. Psychol Rev 99:195-231.

Thompson SM, Wong RKS (1991) Development of calcium current subtypes in isolated rat hippocampal pyramidal cells. J Physiol (Lond) 439:671-689.

Toullec D, Pianetti P, Coste H, Bellenvergue P, Grand-Perret T, Ajakanes $M$, Baudet V, Boissin P, Boursier E, Loriolle F, Duhamel L, Charon D, Kirilovsky J (1991) The bisindolylmaleimide GF $109203 \mathrm{X}$ is a potent and selective inhibitor of protein kinase $\mathrm{C}$. $\mathrm{J}$ Biol Chcm 266:15771-15781.

Westenbroek RE, Ahlijanian MK, Catterall WA (1990) Clustering of L-type $\mathrm{Ca}^{2+}$ channels at the base of major dendrites in hippocampal neurones. Nature 347:281-284.

Westenbroek RE, Hell JW, Warner C, Dubel SJ, Snutch TP, Catterall WA (1992) Biochemical properties and subcellular distribution of an N-type calcium channel $\alpha 1$ subunit. Neuron 9:1099-1115.

Wolkowitz OM, Reus VI, Weingartner H, Thompson K, Doran A, Rubinow D, Picar D (1990) Cognitive effects of corticosteroids. Am J Psychiat 147:1297-1303.

Zeise ML, Teschemacher A, Arrigada J, Zieglgänsberger W (1992) Corticosterone reduces synaptic inhibition in rat hippocampal and neocortical neurons in vitro. J Endocrinol 4:107-112. 